\title{
Environmental Kuznets Curves: Mess or Meaning?
}

\author{
Don J. Webber ${ }^{\alpha \beta}$ and Dave O. Allen ${ }^{\alpha}$ \\ ${ }^{\alpha}$ School of Economics, University of the West of England, Bristol, UK \\ ${ }^{\beta}$ Policy Research Institute, Leeds Metropolitan University, Leeds, UK
}

\begin{abstract}
The shape of the relationship between the rate of environmental degradation and income per capita has been the subject of much empirical examination. When test results based around this so-called 'environmental Kuznets curve' are compared, the empirical evidence is neither consistently supportive of its traditional inverted-U shape nor uniform across pollutants. A deeper understanding of the characteristics of pollutants and of the derived demand and derived supply of pollutants needs to be achieved if environmental Kuznets curves are to be useful.
\end{abstract}

JEL Classification: O49, Q20,

Keywords: Environmental Kuznets Curves, Empirical Evidence.

Corresponding Author: Dr Don J. Webber, School of Economics, 'University of the West of England, Bristol', Frenchay Campus, Bristol, BS16 1QY, UK.

Tel: (+44) 11732 82741; Fax: (+44) 11732 82295. Email: Don.Webber@uwe.ac.uk 


\title{
Environmental Kuznets Curves: Mess or Meaning?
}

\begin{abstract}
The shape of the relationship between the rate of environmental degradation and income per capita has been the subject of much empirical examination. When test results based around this so-called 'environmental Kuznets curve' are compared, the empirical evidence is neither consistently supportive of its traditional inverted-U shape nor uniform across pollutants. A deeper understanding of the characteristics of pollutants and of the derived demand and derived supply of pollutants needs to be achieved if environmental Kuznets curves are to be useful.
\end{abstract}

JEL Classification: O49, Q20,

Keywords: Environmental Kuznets Curves, Empirical Evidence. 


\section{Introduction}

There are two main problems facing environmental policy makers: to ensure that useful knowledge informs policy (without being misused and/or distorted) and to understand how to respond to this knowledge (Boehmer-Christiansen, 1994, p. 140). Policy makers could use the 'environmental Kuznets curve' (often referred to as the EKC), which is thought to illustrate the relationship between income per capita and the rate of environment degradation, as a policy tool for controlling environmental quality. However, although a wealth of empirical literature based around the environmental Kuznets curve exists, it is uncertain to what extent the results are useful for policy formation.

A seminal paper by Nobel Laureate Simon Kuznets (1955) illustrated that the shape of the relationship between income per capita and income inequality is inverted-U. The relationship between income per capita and the rate of environmental degradation takes its name from Kuznets' paper as it is thought to take the same shape. The inverted-U shape environmental Kuznets curve is thought to capture the progression towards ever-higher income per capita, which is initially associated with an increase in the rate of environmental degradation but then, after a turning point, the rate of environmental degradation decreases. This inverse U-shape pattern of income per capita to the rate of environmental degradation, as illustrated in Figure 1, can be thought of as a graphical representation of three stages of development where:

i. Output is initially dominated by agriculture and light assembly, which has a relatively low level of pollution 
ii. Production progresses toward heavy industry, which creates a relatively high level of pollution

iii. The output of high-tech industry subsequently dominates, which generates a relatively low level of pollution.

\{Figure 1 about here $\}$

The presence and position of turning points in environmental Kuznets curves have been the focus of much recent empirical investigation. Two important issues endure: first, are the positions of turning points consistent for different pollutants and, second, can economies increase output to surpass these turning points. In order to shed light on these two issues, this paper attempts to identify whether there are any consistent empirically identifiable relationships between the rate of environmental degradation and income per capita by exploring the empirical literature on the environmental Kuznets curve. Conclusions are drawn to suggest whether the results to date of estimations based around the environmental Kuznets curve are useful for policy formation.

The paper has the following structure. The next section briefly presents a discussion of the 'going-for-growth' perspective where the rate of environmental degradation is perceived to be of peripheral importance to policy makers. It is argued that policy should only be limited in this way if the environmental Kuznets curve has a negative slope and/or if the turning point is accessible for current levels of income. Section 3 is a review of the results of empirical studies that identify curves for different pollutants. Section 5 summarises the most important considerations behind 
whether we can take the environmental Kuznets curve seriously and signals whether progress still needs to be made.

\section{Going for Growth (or perhaps not).}

Many developed countries produce large proportions of high-tech goods, consume less raw resources and have decreasing rates of environmental degradation than countries that have lower levels of income. If countries with higher income levels naturally pollute the environment less, then policies that stimulate growth ought to be good for the environment. The challenge should therefore be to achieve faster economic growth and accelerate out of the high rate of environmental polluting phase, a popularly cited characteristic of middle-income countries, so that the rate of environment degradation slows.

Proponents of this 'going-for-growth' perspective invite the emphasis on achieving faster economic growth rather than on forming environmentally friendly policies because economic growth is perceived to be able to achieve both economic and environmental goals, whereas implementing environmental policies may impede economic growth. Under this philosophy, George W. Bush's announcement "that he had no intention of honouring his campaign pledge to regulate emissions of carbon dioxide" (The Economist, 17/03/01, p. 122) is not disturbing and, indeed, other countries should adopt this 'going-for-growth' stance as well. Economic growth may be necessary to improve the environment but few appear to assert this proposition as much as Beckerman (1992, p. 482) who suggests that "the best - and probably only way to attain a decent environment in most countries is to become rich". 
For LDCs growth could seem to promise only environmental improvement and it might be a powerful way for improving environmental quality. Economic growth may not necessarily deteriorate the environment even at the very low level if, as very low-income countries develop, they could devote more resources (either their own or from foreign aid for example) to improving water supplies and to reducing urban congestion by studying and implementing the knowledge gained from other country's development experiences. However, there is contention as to whether all countries follow similar developmental growth paths and, although it is possible to grow out of some environmental problems, there is nothing automatic about doing so (Shafik and Bandyopadhyay, 1992).

One paper that appears to oppose Beckerman's perspective in principle is Roberts and Grimes (1997) who put the experience of some developed countries down to efficiency improvements in a small number of wealthy countries and a contemporaneous worsening in the performance in poor and middle-income countries. In stark contrast to Beckerman (1992), Roberts and Grimes (1997) suggest a curvilinear relationship (see Figure 2) that deepens and persists due to constraints in poorer countries in the world economy, suggesting that the environmental Kuznets curve is not an evolution of countries passing through various stages of development.

\{Figure 2 about here

It could also be the case that a higher level of education (which generally increases with income) enhances environmental awareness and thereby amplifies the pressure made by inhabitants on policy makers to increase environmental quality or to decrease the rate of environmental degradation. Richer economies have greater means 
available to abate pollution as their governments can increase their expenditure on environmental protection. However, it is not sufficient simply to generate resources that could be spent on environmental protection; they must actually be spent on improving environmental quality (Ekins et al., 1994). Environmentalist movements (such as Greenpeace), who believe that they strive to achieve a better standard of living for future generations, are more prevalent in relatively developed countries. For an analysis of the environmental movement and the affect on policy at the national and international level, see Kamieniecki (1991).

Conclusions obtained from the going-for-growth argument may well apply to rich countries that used to produce a substantial amount of pollution but now produce an output composed of relatively high-tech goods that emit a relatively low rate of pollution, but before we use such theoretical links for policy we need to identify whether this experience is common across countries and across pollutants and establish whether the inverted-U shape environmental Kuznets curve has external validity.

\section{Environmental Kuznets Curve: Empirical Evidence}

If environmental quality and income per capita are related, then there is a case for policy to target income per capita growth to maintain a certain level or improve environmental quality. Empirical studies have presented examinations of data on environmental quality and income per capita in order to identify the shape of the relationship. Before progressing to review case studies, with particular focus on air quality, water quality and deforestation, attention is first directed to the origins of such empirical estimations. 


\section{Early Empirical Studies}

One of the earliest empirical studies to examine the relationship between environmental quality and income per capita is Grossman and Krueger (1991) for urban air quality. They found that "Economic growth tends to alleviate pollution problems once a country's per capita income reaches about $\$ 4,000$ to $\$ 5,000 "$ (1991, p. 35-6). In this sense economic growth and the environment are not necessarily in conflict - economic growth can complement the environment and developing countries domestic policy formation could be geared around growing out of environmental problems. However, there was controversy even from this early stage of empirical investigation as Hettegi et al. (1992) found no evidence to suggest that the inverted U-shape relationship exists for toxic intensity from manufacturing industries. In an analysis of 80 countries between 1960 and 1988, they found that higher manufacturing output actually produces ever-higher toxic intensity. Essentially, Hettegi et al. (1992) suggest that pollution increases with income per capita and output, which raises the question whether the general turning point suggested by Grossman and Krueger exists across pollutants.

This controversy initiated a wealth of empirical studies which attempted to investigate whether the inverted-U shaped relationship is pollutant specific. For instance, Panayotou (1993) presents results that show that as countries surpass a per capita income of $\$ 10,000$ they then begin to shift away from energy intensive heavy industry and into services and IT. If the general turning point is around the $\$ 10,000$ mark, as suggested by Panayotou (1993), then is this an output level that all countries could set out to surpass? A brief examination of Figure 3 illustrates that over half of the countries around the world (60 out of 106 in our sample - which is based on data 
availability) are below this level of output. The medium income per capita $(\$ 8,032)$ is far below the mean $(\$ 11,633)$ and the degree of skewness $(-0.884)$ is definitely towards the bottom end of the distribution. This suggests that if countries that have a real GDP per worker below $\$ 10,000$ all attempt to reach the positive slope that exist after $\$ 10,000$, then there would have to be a considerable deterioration in worldwide environmental quality before the rate of environmental degradation begins to slow.

\{Figure 3 about here $\}$

In addition to the controversy that may exist between pollutants, it is also worth having a quick look at the type of estimation employed in empirical investigations. ${ }^{1}$ As single-equation reduced form models, such as the standard environmental Kuznets curve, do not incorporate structural interrelationships, it is very difficult to identify underlying causal factors are driving the relationship. As the reduced form environmental Kuznets curve is not driven by any particular economic model, there is little theoretical guidance for the correct specification. Instead, we assume that the reduced form model captures the underlying structural model in which income influences technology, the composition of economic output and policy, and any changes in these factors that influence environmental pressure.

It is convention to assume that there is no feedback from the environment on production, and hence there is unidirectional causality from income to the environment. This assumption is particularly problematic when either resource depletion or resource base degradation is involved which have productivity related effects either directly on the economy or indirectly through, for example, its impact

\footnotetext{
${ }^{1}$ A thorough examination is beyond the scope of this paper.
} 
on the population's health. Nevertheless, there are some exceptions. For instance, Unruh and Moomaw (1998) employ a dynamical system that incorporates non-linear feedback systems. Failure to take effective action to reduce particulate emissions in Malaysia is known to have led to increases in mortality rates among urban dwellers (Vincent et al., 1997) and, as we now know, health status is known to be positively related to income (Knowles and Owen, 1995; Webber, 2001).

\section{Air Pollution}

Air pollution can be thought of as a classic free rider problem. As long as the polluter is up wind, then the polluter will not suffer directly from air pollution.

The results of studies into the relationship between air pollutants and income are presented in Table 1. In general, air quality evolves over time and varies across countries. One study of a general improvement in aggregate air pollutants is made by Portney (1998, p. 36) who claims that "the most polluted day in Los Angeles is better (now) than an average or even good day 27 years ago in most of the ... industrial cities" in the US. It initially appears that there is either a negatively sloped relationship with entropy or the environmental Kuznets curve has crossed the x-axis, suggesting some support for an environmental Kuznets curve for aggregate air quality. However, air quality is affected by a variety of individual pollutants and a general proxy for air pollution may not show all of the facts as aggregate emissions of some air pollutants may continue to rise long after the aggregate urban atmospheric concentration has began to decline.

\{Table 1 about here 
One often cited empirical study of the relationship between income and individual air pollutants is Seldon and Song (1994). They examine suspended particle matter (which causes respiratory illnesses and mortality and are largely the result of energy use) nitrogen oxides $\left(\mathrm{NO}_{\mathrm{x}}\right)$ and sulphur dioxide $\left(\mathrm{SO}_{2}\right)$ and identify an environmental Kuznets curve shaped relationship between national output and environmental quality for each pollutant; they do not find a statistically significant relationship between carbon monoxide and income. $\mathrm{SO}_{2}, \mathrm{NO}_{\mathrm{x}}$ and ammonia cause acidification (including acid rain) which can damage ecosystems and buildings. Sulphur dioxides are primarily the result of energy use, and in particular the burning of fuels with high sulphur content and it has a lifetime of about 2-4 days in the atmosphere before it is removed via wet or dry decomposition. Combinations of pollutants in the air can react together, to produce other pollutants, known as secondary pollutants. For example, ozone is made up by a chemical reaction between pollutants in the air. Each of these pollutants were the focus of public attention because suspended particle matter and nitrogen dioxide $\left(\mathrm{NO}_{2}\right)$ contribute to acid rain, while $\mathrm{NO}_{\mathrm{x}}$ contribute to the ground-level ozone problem. Carbon dioxide $\left(\mathrm{CO}_{2}\right)$ contributes to global warming, but has an insignificant direct effect on health. ${ }^{2}$

The results presented by Seldon and Song (1994) are not fully supported by others. For instance, Carson et al. (1997) suggest that the relationship between income and $\mathrm{NO}_{\mathrm{x}}$ is negative, such that it decreases monotonically with income. Although the shape of the environmental Kuznets curve is generally supported for $\mathrm{SO}_{2}$ by most authors (such as Grossman and Krueger, 1995; Panayotou, 1997; Carson et al., 1997), the position of the turning point varies from a low of $\$ 3,670$ (Shafik and Bandyopadhyay, 1992) to a high of $\$ 12,500$ (Kaufmann et al., 1998); this is a

\footnotetext{
${ }^{2}$ At Kyoto in 1997, a breakthrough on combating global warmed seemed on the verge of taking place.
} 
difference of over $340 \%$. Moreover, although the environmental Kuznets curve observed relationship for suspended particle matter is supported by the results of Shafik and Bandyopadhyay (1992), Grossman and Krueger (1991) identified it to be linear with negative slope, while Grossman and Krueger (1995) and Vincent (1997) identify it to be cubic (see Figure 2) (in other words growth at middle-income levels would improve environmental quality but growth at high-income levels would be detrimental). Opschoor (1990) provides intuition to support a cubic shaped relationship; he argues that once technical efficiency improvements in resource use or abatement opportunities have been exhausted or have become too expensive, further income growth will result in net decline in environmental quality.

Shukla and Parikh (1992) investigated the relationship between ambient air quality and city size and how this differs between urban areas across the level of development of countries. Their results do suggest that the positive association between poor air quality and city size is not inevitable and tends to diminish with higher levels of output and the capacity for undertaking pollution abatement measures. It follows that restricting urban growth in developing countries may be neither necessary nor sufficient for achieving environmental gains. Even so, this relationship may be flawed if, because of higher land rents, firms chose to relocate outside of the urban centre and take advantage of improvements in infrastructure; then urban emissions would decrease but over all emissions might continue to rise. Technology appears to have played a favourable role in making improved local air quality possible at an early stage of development (Shafik and Bandyopadhyay, 1992, p. 10).

38 industrialised countries agreed to take on the task of reducing greenhouse gasses by a global total of $5.2 \%$ by 2010 . 
Dijkgraaf and Vollebergh (1998) estimate environmental Kuznets curves for $\mathrm{CO}_{\mathrm{x}}$ and identify time series regressions coefficients that vary widely with significant linear, inverted-U, U, and cubic shaped environmental Kuznets curves being identified in individual country regressions.

Why are there differences in these relationships? One reason could be the variety of economies incorporated in the sample for empirical examination. For instance, Hettegi et al. (1992) found that the rate of toxic intensity grew faster in LDCs than in the more developed countries while Holtz-Eakin and Seldon (1995) found that global carbon dioxide emissions will continue to grow at about $1.8 \%$ per annum for the foreseeable future because output and population will continue to growth most rapidly in lower income countries will high marginal propensities to emit carbon dioxide. If there is a continued increase in demand for and supply of LDCs' goods then there is bound to be an increase in pollution in the world's atmosphere through increased output. However, this 'scale' effect may be outweighed by changes in the composition of production towards services and innovations of technologies (driven by markets or government regulation) that pollute less.

\section{Water Quality}

Water pollution can also be a classic free rider problem. As long as the polluter is further up the catchment area than the area that is being polluted, then the polluter will not suffer directly from the pollution.

Water is essential for sustaining life. Increasing income might increase production and therefore pollution, but this may be bearable if the benefits that accrue to the population outweigh the costs. At the very low level of income per capita, an 
increase in income per capita can improve sanitation and increase the number of watering holes. A lack of clean water and urban sanitation both improve uniformly with increasing income and over time (Shafik and Bandyopadhyay, 1992) and a lack of clean water affects productivity. In Bangladesh, diarrheal diseases also account for about one in five deaths in all age groups (Beckerman, 1992, p. 489). Economic growth could enhance the health of individuals by increasing stamina, flexibility and agility and thereby stimulate economic growth (Webber and Perlo-Freeman, 2005).

There is a wealth of evidence to suggest that increasing income will not be beneficial to water quality, as the shape of the environmental Kuznets curve relationship for water quality is not usually found to be either negatively sloped or inverted-U shaped. Most empirical studies identify that the quality of water supplies and income are positively related (see for example Shafik and Bandyopadhyay, 1992; Vincent, 1997; Hettige et al., 2000). A summary of empirical results for water quality is presented in Table 2. Two exceptions to this rule are identified. Grossman and Krueger (1995, p. 370) find that "water quality appear[s] to benefit from economic growth once some critical level of income has been reached", suggesting an environmental Kuznets curve type relationship, while Shafik and Bandyopadhyay’s (1992) results suggest a cubic shaped relationship for faecal coliforms. Controversy is increased with the findings from Hettige et al. (2000) who identify that although there appears to be a positive relationship between income and industrial water pollution, water quality appears to stabilise after middle-income. The consensus of the opinion is therefore that water quality decreases with income, albeit up to a point.

\{Table 2 about here 


\section{Forests}

Is there an environmental Kuznets curve for deforestation? Mather et al. (1999, p. 59) examine data from countries across the world and identify that "the rate of deforestation initially increases as income rises but then decreases and gives way to reforestation". This is evidence to suggest that there is an inverted U-shaped environmental Kuznets curve for forests, but might merely be illustrating that people in richer countries have more time to spend on leisure activities which includes gaining utility from the countryside which could generate increasing pressure from environmental pressure groups to reforest.

Economic growth and positive forest trends are not incompatible. Patel et al. (1995) investigate smallholder wood production in East Africa and they too found that "as land continues to be subdivided tree cover tree cover may actually rise" (p. 516). Results of empirical studies into the relationship between deforestation and income are presented in Table 3.

\{Table 3 about here $\}$

However, support for an environmental Kuznets curve for deforestation may not be so simple. Mather et al. (1999) stress that "there would seem to be some evidence to suggest that developing and developed countries respectively pass through phases of rapid deforestation and reforestation in the course of economic growth ... (and although) the relationship between forest change and income is not close ... a statistically significant relationship exists" (p. 60). Stronger evidence of rejection of the environmental Kuznets curve for forests is identified by Shafik and 
Bandyopadhyay (1992), who find that "per capita income appears to have very little bearing on the rate of deforestation" (p. 7) while Cropper and Griffiths (1994) conclude that economic growth will clearly not solve the problem of deforestation as any turning point is at such high levels of income per capita. ${ }^{3}$ Indeed there are asymmetries depending where in the world the sample is collected; for instance, Panayotou (1993) found deforestation to be much greater in tropical areas and in countries with higher population densities. Lekakis (2000) who, while emphasising that the worst waves of fires ever to occur in Greece happened in the summer of 1998, find that the relationship between the forest environment and output is somewhat indirect as natural disasters also impact heavily on the forest environment.

\section{Other Pollutants}

Case studies have been conducted for other measures of environmental quality or emission rates. These range from overgrazing of land (Lekakis, 2000) to automotive lead emissions (Hilton and Levinson, 1998) to the number to environmental offences (Lekakis, 2000). Relatively few empirical papers have presented counter claims for the shape of respective environmental Kuznets curves, but this is not necessarily due to the lack of publication due to a lack of a new story. Instead it might merely be because of the lack of empirical estimations due to data availability and time constraints on researchers. In what follows, the results of empirical estimations into the relationships between different measures of environmental quality or rates of environmental degradation and income are presented and the shapes of the environmental Kuznets curves that result are compared. Direct comparison is

\footnotetext{
${ }^{3}$ A last minute piece of legislation by Bill Clinton scuppered George W. Bush's ambitions to cut down
} 
obviously not practicable, but the purpose of this sub-section is to highlight the fact that results of environmental Kuznets curve estimations suggest a variety of different shapes.

The results presented in Table 4 suggest that the shape of the environmental Kuznets curve for (household and automotive) lead emissions and hazardous wastes are inverted-U shaped, implying that environmental degradation accelerates faster at low incomes and slows after a turning point after higher levels of income. As richer cities tend to produce more garbage, the composition of which tends to be very different than poor countries. Other empirical studies suggest that the shape of the environmental quality-income relationship is positive for municipal wastes, overgrazing and the number of environmental offences committed. In contrast, a negative relationship is found for volatile organic carbon and bio-chemical oxygen demand and a cubic relationship is identified for chemical oxygen demand. Low levels of dissolved oxygen, usually caused by human sewage or agro-industrial effluent, reduce the capacity of rivers to support aquatic life.

\{Table 4 about here $\}$

Focusing on lead emissions, it is unclear whether the relationship is direct. Hilton and Levinson (1998) argue that automotive lead pollution is the product of two separate factors: lead per gallon (pollution intensity) and petrol consumption (pollution activity) and conclude that the declining portion of the environmental Kuznets curve "depends critically in the reduction in gasoline lead content, not gasoline consumption" (p. 127) and that "None of the decline in lead pollution has 
come from decreases in polluting activity" (p. 138). Hence, as a nation grows it consumes more and more; only if an economy changes what it consumes, or changes how the good is produced, will environmental quality rise and the rate of environmental degradation fall.

\section{Conclusions}

The purpose of this paper was to review the empirical literature on the environmental Kuznets curve and to draw any useful lessons that might be useful for policy makers. The evidence suggests that there is an aggregate relationship between specific environmental pollutants and income per capita, however the shape of the relationship is not uniform across pollutants and turning points, when they exist, differ across pollutants. This leads to the conclusion that there is no single relationship between income and environmental quality and the rate of environmental degradation. It is possible to grow out of some types of environmental degradations, but whether this is the case will depend on the type of pollution that is under examination. Policy makers should recognise the deficiencies of the theory behind the environmental Kuznets curve.

Even if environmental Kuznets curves do exist, several decades may pass before turning points are reached, and extensive environmental degradation may occur in the mean time. The turning point on the environmental Kuznets curve is probably associated with the dynamics of individual environmental elements that change with income. Progress still needs to be made in order to learn which variables do have turning points in their relation with output so that we can decide which

9, 2001, p. 10). 
policies to follow. If a massive increase in pollution is to be avoided, a proactive and explicit approach to environmental quality is needed across countries.

Acknowledgements: Paul Dunne, Peter Howells, Brian Garrod and Richard O'Doherty are thanked for their useful comments. Any remaining errors are the authors' responsibility. 


\section{Bibliography}

Agras, J. and Chapman, D. (1999) "A dynamic approach to the environmental Kuznets curve hypothesis", Ecological Economics 28, 267-77

Andreoni, J. and Levinson, A. (2000) "The simple analytics of the environmental Kuznets curve", downloaded from www.georgetown.edufaculty/aml6/cruesoe.pdf on 27/03/00

Arrow, K., Bolin, B., Costanza, R., Dasgupta, P., Folke, C., Holling, C. S., Jansson, B-O., Levin, S., Mäler, K-G., Perrings, C. and Pimental, D. (1995) "Economic growth, carrying capacity and the environment", Science 268, (Policy Forum) 520-1

Ayres, R. U. (1998) "Eco-thermodynamics: economics and the second law", Ecological Economics 26, 189-209

Barbier, E. B. (1997) "Introduction to the environmental Kuznets curve special issue", Environmental and Development Economics 2, 369-81

Beckerman, W. (1992) "Economic growth and the environment: whose growth? Whose environment?" World Development 20, 481-96

Berrens, R.P., Bohara, A.K., Gawande, K. and Wang, P. (1997) "Testing the inverted-U hypothesis for US hazardous waste: An application of the generalised gamma model”, Economics Letters 55, 43540

Boehmer-Christiansen, S. (1994) "Global climate protection policy: the limits of scientific advice", Global Environmental Change 4, 140-59

Brouwer, R. (2000) "Environmental value transfer: state of the art and future prospects", Ecological Economics 32, 137-52

Carson, R.T., Jeon, Y. and McCubbin, D.R. (1997) "The relationship between air pollution emissions and income: US data", Environment and Development Economics 22, 433-50

Cen, T-Y (2001) "The impact of mitigating CO2 emissions on Taiwan's economy", Energy Economics 23, $141-51$

Cole, M. A., Rayner, A. J. and Bates, J. M. (1997) "The environmental Kuznets curve: an empirical analysis", Environment and Development Economics 2, 401-16

Corvello, V.T. and Frey, R.S. (1990) "Technology-based environmental health risks in developing nations", Technological Forecasting and Social Change 37, 159-79

de Bruyn, S.M. (1997) "Explaining the environmental Kuznets curve: structural change and international agreements in reducing sulphur emissions", Environmental and Development Economics 2, 485-503

de Bruyn, S.M., van den Bergh, J.C.J.M. and Opschoor, J.B. (1998) "Economic growth and emissions: reconsidering the empirical basis of environmental Kuznets curves", Ecological Economics 25, 16175

Dijkgraaf, E. and Vollebergh, H. R. J. (1998) "Growth and/or Environment: Is there a Kuznets curve for carbon emissions?" paper presented at the $2^{\text {nd }}$ biennial meeting of the European Society for ecological economics, Geneva, $4^{\text {th }}-7^{\text {th }}$ March

Douthwaite, R. (1992) The Growth Illusion: How economic growth has enriched the few, impoverished the many, and endangered the planet, Lilliput Press Ltd, Dublin, Ireland

Ekins, P. (1997) "The Kuznets curve for the environmental and economic growth: examining the evidence", Environment and Planning A 29, 805-30

Ekins, P., Folke, C. and Costanza, R. (1994) "Trade, environment and development: the issues in perspective", Ecological Economics 9, 1-12

Esty, D.C. and Mendelshon, R. (1998) "Moving from national to international environmental policy", Policy Studies 31, 225-35

Galeotti, M. and Lanza, A. (1999) "Richer and cleaner? A study on carbon dioxide emissions in developing countries", Energy Policy 27, 565-73

Gangadharan, L. and Valenzuela M. R. (2001) "Interrelationships between income, health and the environment: extending the environmental Kuznets curve hypothesis", Ecological Economics 36, 513-31

Gomez, M. T. (1999) "El cambio climático en el desarrollo económico: revision de la hipótesis de Kuznets", Desarrollo Y Sociedad 43, 173-212

Goulder, L.H. and Mathai, K. (2000) "Optimal $\mathrm{CO}_{2}$ abatement in the presence of induced technical change", Journal of Environmental Economics and Management 39, 1-38

Greening, L. A. , Ting, M. and Krackler, T. J. (2001) "Effects of changes in residential end-uses and behaviour on aggregate carbon intensity: comparison of 10 OECD countries for the period 1970 through 1993", Energy Economics 23, 153-78 
Grossman, G.M. and Krueger, A.B. (1991) "Environmental impacts of a North-American free trade agreement", NBER Working Paper 3914

Grossman, G.M. and Krueger, A.B. (1995) "Economic growth and the environment”, Quarterly Journal of Economics 110, 353-77

Hahn, R.W. and Stavins, R.N. (1992) "Economic incentives for environmental protection: integrating theory and practice", American Economic Review, Papers and Proceedings 82, 464-8

Halkos, G. E. and Tsionas, E. G. (2001) "Environmental Kuznets curves: bayesian evidence from switching regime models", Energy Economics 23, 191-210

Harbaugh, W. T., Levinson, A. and Wilson, D. M. (2001) "Reexamining the empirical evidence for an environmental Kuznets curve", Downloaded on $2^{\text {nd }}$ March 2001 from http://www.georgetown.edu/faculty/aml6/pdfs\&zips/EKC\%20paper.pdf at 12.19 GMT

Heston, A. and Summers, R (1995) "The Penn World Table (Mark 5): An expanded set of international comparisons, 1950-1992”, Quarterly Journal of Economics 110, 327--368.

Hettige, H., Lucas, R.E.B. and Wheeler, D. (1992) "The toxic intensity of industrial production: global patterns, trends and trade policy", American Economic Review, Papers and Proceedings 82, 478-81

Hettige, H. Singh, M., Pargal, S. and Wheeler, D. (1997) "Formal and informal regulation of industrial pollution: comparative evidence from the Indonesia and US", World Bank Economic Review 11.

Hettige, H., Mani, M. and Wheeler, D. (2000) "Industrial pollution in economic development: the environmental Kuznets curve revisited", Journal of Development Economics 62, 445-76

Hilton, F.G.H. and Levinson, A. (1998) "Factoring the environmental Kuznets curve: evidence from automotive lead emissions", Journal of Environmental Economics and Management 35, 126-41

Holtz-Eakin, D. and Seldon, T.M. (1995) "Stoking the fires? $\mathrm{CO}_{2}$ emissions and economic growth", Journal of Public Economics 57, 86-101

John, A. and Pecchenino, R. (1994) "An overlapping generations model of growth and the environment" Economic Journal 104, 1393-410

Kahn, M. E. (1995) "Micro evidence on the environmental Kuznets curve", Columbia University Working Paper

Kahn, M.E. (1998) “A household level environmental Kuznets curve”, Economics Letters 59, 269-73

Kamieniecki, S. (1991) "Political Mobilisation, agenda building and international environmental policy”, Journal of International Affairs 44, 339-59

Kaufmann, R.K., Davidsdottir, B., Garnham, S. and Pauly, P. (1998) "The determinants of atmospheric $\mathrm{SO}_{2}$ concentrations: reconsidering the environmental Kuznets curve”, Ecological Economics 25, 209-20

Knowles, S. and Owen, D. (1995) "Health capital and cross-country variation in income per capita in the Mankiw-Romer-Weil model", Economics Letters 48, 99-106.

Komen, M. H. C., Gerking, S. and Folmer, H. (1997) "Income and environmental R\&D: empirical evidence from OECD countries", Environment and Development Economics 2, 505-15

Koop, G. and Tole, L. (1999) "Is there an environmental Kuznets curve for deforestation?" Journal of Development Economics 58, 231-44

Kriström, B. (2000) "Growth, Employment and the Environment”, Swedish Economic Policy Review 7, 155-84

Kuznets, S. (1955) "Economic growth and income inequality", American Economic Review 45, 1-28

Lekakis, J.N. (2000) "Environment and development in a southern European country: which environmental Kuznets curves?" Journal of Environmental Planning and Management 43, 139-53

Lekakis, J. N. and Kousis, M. (2001) "Demand for and supply of environmental quality in the environmental Kuznets curve hypothesis”, Applied Economics Letters 8, 169-72.

List, J.A. and Gallet, C.A. (1999) "The environmental Kuznets curve: does one size fir all?" Ecological Economics 31, 409-42

Lopez, R. (1994) "The environment as a factor of production: the effects of economic growth and trade liberalisation”, Journal of Environmental Economics and Management 27, 163-84

Lopez, R. and Siddhartha, M. (2000) "Corruption, pollution and the Kuznets environmental curve", Journal of Environmental Economics and Management 40, 137-50

Magnani, E. (2000) "The environmental Kuznets curve, environmental protection policy and income distribution", Ecological Economics 32, 431-43

Mather, A.S., Needle, C.L. and Fairbairn, J. (1998) "Environmental Kuznets curves and forest trends", Geography 84, 55-65

McConnell, K. E. (1997) "Income and the demand for environmental quality", Environmental and Development Economics 2, 383-99

Moomaw, W. R. and Tullis, D. M. (1994) "Carbon dioxide development paths", In: Solow, R. et al. (Eds.), Industrial Ecology and Global Change, Cambridge University Press, 157-72 
Moomaw, M. R. and Unruh, G. C. (1997) "Are environmental Kuznets curves misleading us? The case of $\mathrm{CO}_{2}$ emissions", Environmental and Development Economics 2, 451-63

Munasinghe, M. (1999) "Is environmental degradation and inevitable consequence of economic growth: tunnelling through the environmental Kuznets curve", Ecological Economics 29, 89-109

Opschoor, J. B. (1990) "Ecologisch duurzame economische ontwikkeling: Een theoretisch idee en een weerbarstige praktijk". In Nijkamp, P. and Verbruggen, H. (Eds.) Het Hederlands milieu in de Europese ruimte: Preadviezen van de kononklijke vereniging voor staathuishoudkunde, Stenfert Kroese, Leiden, 77-126.

Östblom, G. (1998) "The environmental outcome of emissions-intensive economic growth: a critical look at official growth projections for Sweden up to the year 2000”, Economic Systems Research 10, 19-29

Panayotou, T. (1993) "Empirical tests and policy analysis of environmental degradation at different stages of economic development", World Employment Programme Research Working Paper WEP222/WP 238

Panayotou, T. (1997) "Dymistifying the Environmental Kuznets curve", Environment and Development Economics 2, 505-15

Panayotou, T. (2000) "Globalisation and the environment", CID, Harvard University, Working Paper 53

Panayotou, T. (2000) "Economic growth and the environment", CID, Harvard University Working Paper 56

Patel, S.H., Pinckney, T.C. and Jaeger, W.K. (1995) "Smallholder wood production and population pressure in East Africa: evidence of an environmental Kuznets curve?" Land Economics 71, 516-30

Pearson, P. J. G. (1994) "Energy, externalities and environmental quality: Will development cure the ills it creates?", Energy Studies Review 6, 199-216

Perman, R. and Stern, D.I. (1999) "The environmental Kuznets curve: implications of nonstationarity", downloaded from http://cres.anu.edu.au/ dstern/anzsee/eep9901.pdf on 27/03/00

Picton, T. and Daniels, P.L. (1999) "Ecological restructuring for sustainable development: evidence from the Australian economy", Ecological Economics 29, 405-42

Portney, P.R. (1998) "Counting the cost: the growing role of economics in environmental decisionmaking”, Environment 40, 14-18 and 36-8

Roberts, J.T. and Grimes, P.E. (1997) "Carbon intensity and economic development 1962-91: a brief exploration of the environmental Kuznets curve", World Development 25, 191-8

Rock, (1996) "Pollution intensity of GDP and trade policy: Can the World Bank be wrong?" World Development 24, 471-9

Rosen (1974)

Rothman, D.S. (1998) "Environmental Kuznets curves - real progress or passing the buck? A case for consumption-based approaches", Ecological Economics 25, 177-94

Rugman, A.M. and Verbeke, A. (1998) "Corporate strategy and international environmental policy", Journal of International Business Studies 29, 819-34

Schmalensee, R., Stoker, T. M. and Judson, R. A. (1998) "World carbon dioxide emissions: 19502050", Review of Economics and Statistics 80, 15-27

Seldon, T.M. and Song, D. (1994) "Environmental quality and development: is there a Kuznets curve for air pollution emissions?" Journal of Environmental Economics and Management 27, 147-62

Seldon, T. M. and Song, D. (1995) "Neoclassical growth, the J curve for abatement and the inverted U curve for pollution" Journal of Environmental Economics and Management 29, 162-8

Sengupta, R. (1996) " $\mathrm{CO}_{2}$ emission-income relationship: policy approach for climate control”, Pacific and Asian Journal of Energy 7, 207-29

Shafik, N. (1994) "Economic development and environmental quality: an econometric analysis", Oxford Economic Papers 46, 757-73

Shafik, N. and Bandyopadhyay, S. (1992) "Economic growth and environmental quality: time series and cross-country evidence", World Bank Policy Research Working Paper WPS904

Shukla, V. and Parikh, K. (1992) "The environmental consequences of urban growth: cross-national perspectives on economic development, air pollution and city size", Urban Geography 12, 422-49

Sprinz, D. and Vaahtoranta, T. (1994) "The interest-based explanation of international environmental policy", International Organisation 48, 77-105

Stern, D.I. (1996) "Progress on the environmental Kuznets curve?" The Australian National University Centre for Resource and Environmental Studies Working Paper 9601

Stern, D.I., Common, M. and Barbier, E.B. (1996) "Economic growth and environmental degradation: the environmental Kuznets curve and sustainable development”, World Development 24, 1151-60 
Stern, D. I., Auld, T., Common, M. S. and Sanyal, K. K. (1998) "Is there an environmental Kuznets curve for sulphur?” Australian National University, Working Paper 9804.

Stokey, N.L. (1998) “Are there limits to growth?” International Economic Review 39, 1-31

Suri, V. and Chapman, D. (1998) "Economic growth, trade and energy: Implications or the environmental Kuznets curve", Ecological Economics 25, 195-208

Torras, M. and Boyce, J.K. (1998) "Income, inequality and pollution: a reassessment of the environmental Kuznets curve", Ecological Economics 25, 147-60

Tucker, M. (1995) "Carbon dioxide emissions and global GDP”, Ecological Economics 15, 215-23

Unruh, G. C. and Moomaw, W.R. (1998) "An alternative analysis of apparent EKC-type transitions”, Ecological Economics 25, 221-9

Vincent, J.R. (1997) "Testing for environmental Kuznets curves within a developing country", Environment and Development Economics 2, 417-32

Vincent, R. J., Rozali, B. M. A. and Associates (1997) Environment and development in a resourcerich economy: Malaysia under the new economic policy, Harvard University Press, Cambridge, MA.

Wang, P., Bohara, A.K., Berrens, R.P. and Gawande, K. (1998) "A risk-based environmental Kuznets curve for US hazardous waste sites", Applied Economics Letters 5, 761-3

Webber, D. J. and Perlo-Freeman, S. (2005) "Economic growth and basic needs fulfilment".

World Bank (1992) World Bank Development Report 1992: Development and the Environment, World Bank, Washington DC.

Zaim, O. and Taskin, F. (2000) "A Kuznets Curve in Environmental Efficiency: An Application on OECD Countries", Environmental and Resource Economics 17, 21-36

Zhang, A. (2000) "Decoupling China's carbon emissions increase from economic growth: An economic analysis and policy implications", World Development 4, 739-52 


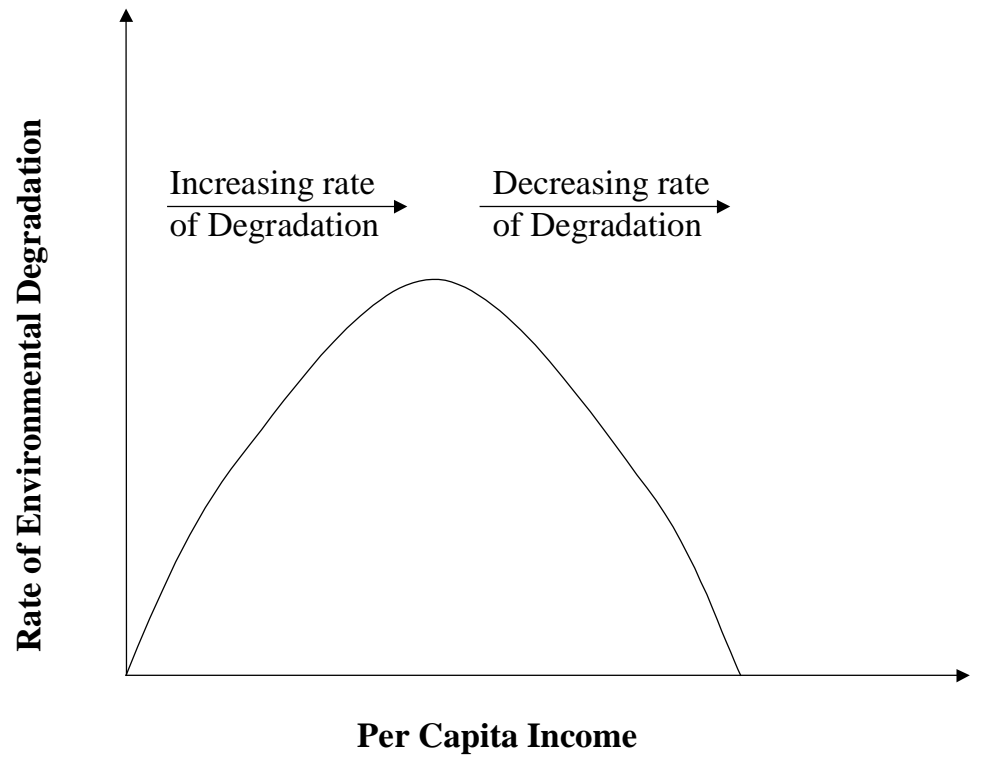

Figure 1: The Simple Environmental Kuznets Curve 


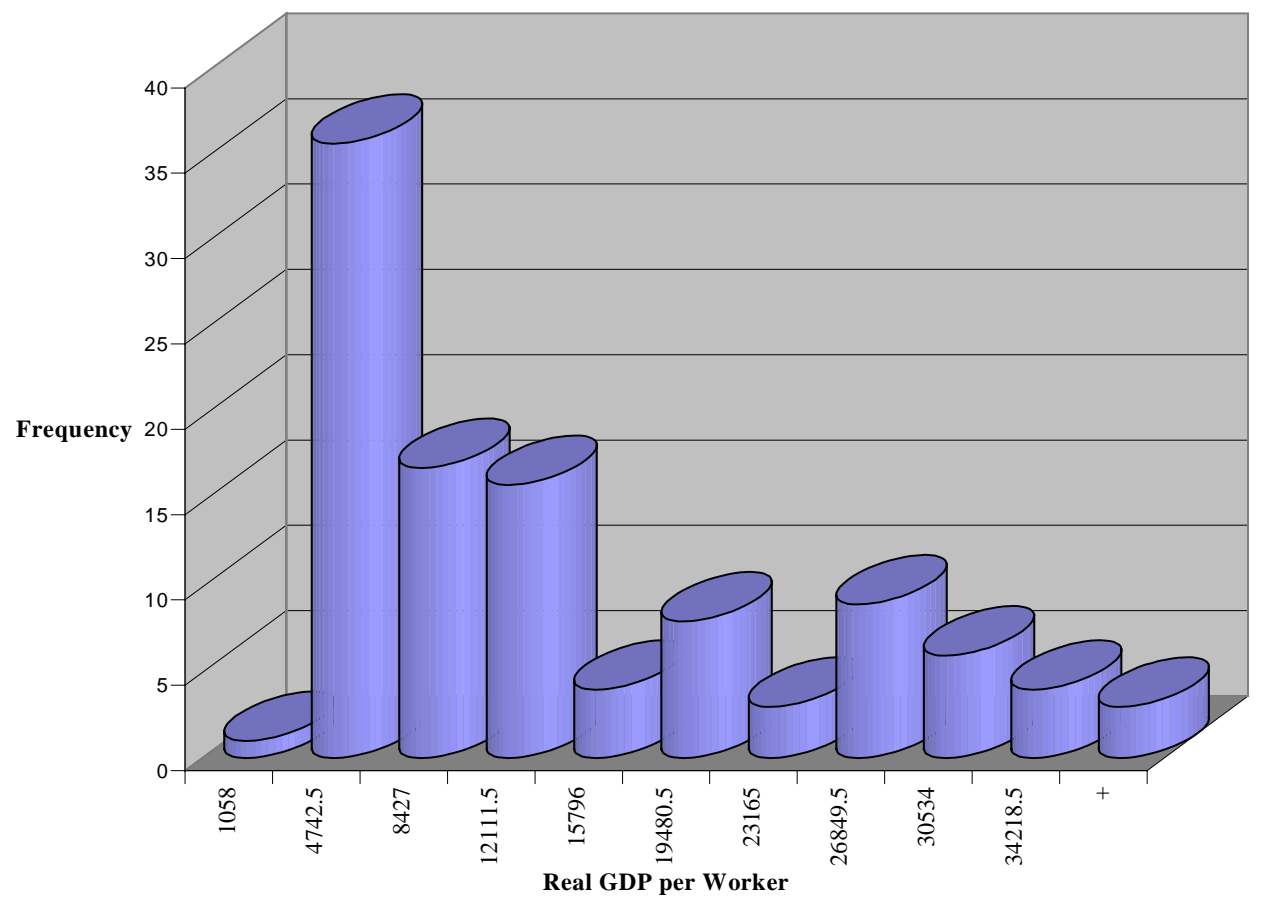

Figure 2: Frequency of Countries according to their Real GDP per Worker in 1990 (in 1985 international prices). Source: Heston and Summers (1995) 


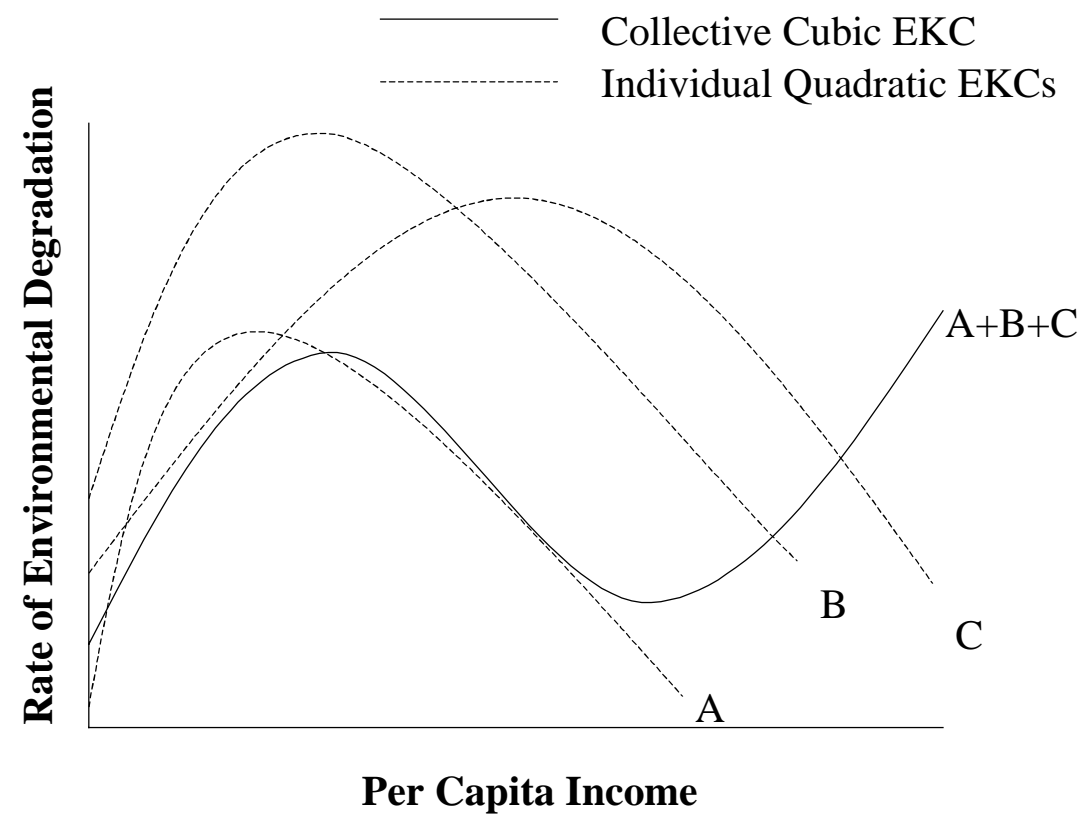

Figure 3: Different shapes of the Environmental Kuznets Curve 
Table 1: Air Pollutants

\begin{tabular}{|c|c|c|c|}
\hline Case Study & Author(s) & Shape & $\begin{array}{c}\text { Turning Point }(\mathbf{s}) \\
{[\$ \text { per capita }(1985)]}\end{array}$ \\
\hline \multirow{4}{*}{ Nitrogen Oxides } & "Seldon and Song (1994) & Inverted-U & $\$ \$ \$ 21,800$ \\
\hline & Panayotou (1993) & Inverted- $\mathrm{U}^{\mathrm{X}}$ & $\$ 5,500$ \\
\hline & Cole et al. (1997) & Inverted-U & $\$ 14,700$ \\
\hline & Carson et al. (1997) & Linear with negative slope ${ }^{X}$ & N/A \\
\hline \multirow{3}{*}{ Carbon Monoxide } & Seldon and Song (1994) & No Significant Shape & N/A \\
\hline & Cole et al. (1997) & Inverted-U & $\$ 9,900$ \\
\hline & Carson et al. (1997) & Linear with negative slope $\mathrm{X}^{\mathrm{X}}$ & N/A \\
\hline \multirow{13}{*}{ Carbon Dioxide } & Shafik and Bandyopadhyay (1992) & Linear with positive slope & N/A \\
\hline & World Bank (1992) & Linear with positive slope & N/A \\
\hline & Shafik (1994) & Linear with positive slope & N/A \\
\hline & Moomaw and Tullis (1994) & Inverted-U (for France) & $\$ 10,763$ \\
\hline & Tucker (1995) & Increases at a decreasing rate & N/A \\
\hline & Holtz-Eakin and Seldon (1995) & Inverted-U & $\$ 35,428(1986$ \$US) \\
\hline & Sengupta (1996) & Cubic & $\$ 8,740$ and $\$ 15,300$. \\
\hline & Cole et al. (1997) & Inverted-U & $\$ 25,100$ \\
\hline & Roberts and Grimes (1997) & Inverted-U, though increasingly curvilinear & $\$ 8,000$ \\
\hline & Moomaw and Unruh (1997) & Cubic & $\$ 12,800$ \\
\hline & Unruh and Moomaw (1998) & Inverted-U (for many individual countries) $^{\mathrm{X}}$ & $\begin{array}{c}\text { Range from } \$ 8,884 \\
\text { (Austria) to } \$ 15,425 \text { (USA) }\end{array}$ \\
\hline & Agras and Chapman (1999) & No significant shape ${ }^{\mathrm{D}}$ & N/A \\
\hline & Galeotti and Lanza (1999) & Inverted-U $\mathrm{U}^{\mathrm{DPM}}$ & $\begin{array}{l}\$ 15,073 \text { and } \$ 21,757 \\
(1990 \mathrm{PPP})\end{array}$ \\
\hline \multirow{15}{*}{ Sulphur Dioxide } & Grossman and Krueger (1991) & Inverted-U & $\$ 4,000-\$ 5,000$ \\
\hline & Shafik and Bandyopadhyay (1992) & Inverted-U & $\$ 3,670$ \\
\hline & Panayotou (1993) & Inverted- $\mathrm{U}^{\mathrm{X}}$ & $\$ 2,894$ \\
\hline & Shafik (1994) & Inverted-U & $\$ 3,670$ \\
\hline & Seldon and Song (1994) & Inverted-U & $\$ 8,916$ \\
\hline & Panayotou (1993) & Inverted-U $\mathrm{U}^{\mathrm{X}}$ & $\$ 5,000$ \\
\hline & Grossman and Krueger (1995) & Inverted-U & $\$ 4,053$ \\
\hline & Panayotou (1997) & $\begin{array}{l}\text { Inverted-U (negatively sloped once the income effect } \\
\text { is decomposed into constituent scale, structure and } \\
\text { abatement) } \mathrm{X}\end{array}$ & Just under $\$ 5,000$ \\
\hline & Cole et al. (1997) & Inverted-U & $\$ 6,900$ \\
\hline & Carson et al. (1997) & Linear with negative slope ${ }^{X}$ & N/A \\
\hline & Torras and Boyce (1998) & Cubic (excluding inequality) & $\$ 3890$ and $\$ 15425$ \\
\hline & Torras and Boyce (1998) & Cubic (including inequality) & $\$ 3360$ and $\$ 14034$ \\
\hline & Stern et al. (1998) & Inverted-U & $\$ 78,703$ \\
\hline & Kaufmann et al. (1998) & $\begin{array}{l}\text { Inverted-U between economic activity and } \\
\text { atmospheric concentration of } \mathrm{SO}_{2}\end{array}$ & $\$ 12,346$ \\
\hline & Kaufmann et al. (1998) & $\begin{array}{l}\text { Quadratic between GDP per capita and atmospheric } \\
\text { concentration of } \mathrm{SO}_{2}\end{array}$ & $\$ 12,500$ \\
\hline \multirow{9}{*}{$\begin{array}{l}\text { Suspended } \\
\text { Particulate Matter }\end{array}$} & Grossman and Krueger (1991) & Linear with negative slope & N/A \\
\hline & Shafik and Bandyopadhyay (1992) & Inverted-U & $\$ 3,280$ \\
\hline & Seldon and Song (1994) & Inverted-U & $\$ 9,600$ \\
\hline & Shafik (1994) & Inverted-U & $\$ 3,280$ \\
\hline & Grossman and Krueger (1995) & Cubic & $\$ 10,000-\$ 15,000$ \\
\hline & Panayotou (1993) & Inverted- $\mathrm{U}^{\mathrm{X}}$ & $\$ 4,500$ \\
\hline & Cole et al. (1997) & Inverted-U & $\$ 7,300$ \\
\hline & Carson et al. (1997) & Linear with negative slope ${ }^{X}$ & N/A \\
\hline & Vincent (1997) & Cubic & Never has a negative slope \\
\hline \multirow{3}{*}{ Smoke } & Grossman and Krueger (1995) & Inverted-U & \\
\hline & Torras and Boyce (1998) & Cubic (excluding inequality) & $\$ 4350$ and $\$ 10510$ \\
\hline & Torras and Boyce (1998) & No significance shape (including inequality) & N/A \\
\hline Air Toxins & Carson et al. (1997) & Linear with negative slope & N/A \\
\hline \multirow{3}{*}{ Heavy Particles } & Grossman and Krueger (1995) & Linear with Negative Slope & N/A \\
\hline & Torras and Boyce (1998) & Linear with positive slope (excluding inequality) & N/A \\
\hline & Torras and Boyce (1998) & No significant relationship (including inequality) & N/A \\
\hline CFCs & Cole et al. (1997) & Inverted-U (log quadratic function) $)^{X}$ & $\$ 12,600$ \\
\hline Dark Matter & Grossman and Krueger (1991) & Inverted-U & \\
\hline VOC & Carson et al. (1997) & Linear with negative slope ${ }^{X}$ & N/A \\
\hline Greenhouse Gasses & Carson et al. (1997) & Linear with negative slope ${ }^{X}$ & N/A \\
\hline
\end{tabular}

Notes: $\mathrm{X}$ after shape implies cross-sectional estimations. LF implies the use of an econometric method that permits non-linear feedback in a dynamical system. DPM implies the use of a dynamic price model. D implies dynamic modelling approach. Otherwise, empirical estimations are either time-series-cross-sections or panel. 
Table 2: Water Pollutants

\begin{tabular}{|c|c|c|c|}
\hline Case Study & Author(s) & Shape & $\begin{array}{c}\text { Turning Point(s) } \\
{[\$ \text { per capita }(1985)]}\end{array}$ \\
\hline \multirow{3}{*}{$\begin{array}{l}\text { Dissolved Oxygen in } \\
\text { Rivers }\end{array}$} & "Shafik and Bandyopadhyay (1992) & Linear with positive slope & N/A \\
\hline & Torras and Boyce (1998) & Monotonic increase (excluding inequality) & N/A \\
\hline & Torras and Boyce (1998) & Cubic (including inequality) & $\$ 19,865$ and $\$ 5,085$ \\
\hline \multirow{4}{*}{$\begin{array}{l}\text { Access to Clean } \\
\text { (safe) Water }\end{array}$} & Shafik and Bandyopadhyay (1992) & Linear with positive slope & N/A \\
\hline & Shafik (1994) & Linear with negative slope & N/A \\
\hline & Torras and Boyce (1998) & Cubic (excluding inequality) & $\$ 11,255$ and $\$ 14,925$ \\
\hline & Torras and Boyce (1998) & Cubic (including inequality) & $\$ 6900$ and $\$ 20,215$ \\
\hline pH & Vincent (1997) & Linear with positive slope & N/A \\
\hline $\begin{array}{l}\text { Ammoniacal } \\
\text { Nitrogen in Water }\end{array}$ & Vincent (1997) & No trend in aggregate; Linear with positive slope at state level & N/A \\
\hline \multirow{2}{*}{$\begin{array}{l}\text { Chemical Oxygen } \\
\text { Demand } \\
\end{array}$} & Vincent (1997) & Quadratic & Not given \\
\hline & Grossman and Krueger (1995) & Inverted-U & $\$ 7,853$ \\
\hline \multirow{2}{*}{$\begin{array}{l}\text { Bio-chemical Oxygen } \\
\text { Demand }\end{array}$} & Vincent (1997) & Falls rapidly with middle-income and then flattens out & N/A \\
\hline & Grossman and Krueger (1995) & Inverted-U & $\$ 7,623$ \\
\hline $\begin{array}{l}\text { Industrial Water } \\
\text { Pollution }\end{array}$ & Hettige et al. (2000) & Rises rapidly through middle-income and then flattens out ${ }^{\mathrm{X}}$ & N/A \\
\hline \multirow{5}{*}{ Faecal Coliforms ${ }^{4}$} & Shafik and Bandyopadhyay (1992) & Cubic & $\$ 1,375$ and $\$ 11,400$ \\
\hline & Shafik (1994) & Cubic & $\$ 1,375$ and $\$ 11,400$ \\
\hline & Grossman and Krueger (1995) & Inverted-U & $\$ 7,955$ \\
\hline & Torras and Boyce (1998) & Linear with positive slope (excluding inequality) & N/A \\
\hline & Torras and Boyce (1998) & No significant trend (including inequality) & N/A \\
\hline Total Coliforms & Grossman and Krueger (1995) & Cubic & \\
\hline Cadmium & Grossman and Krueger (1995) & Constant & N/A \\
\hline Lead & Grossman and Krueger (1995) & Linear with negative slope & N/A \\
\hline \multirow{2}{*}{ Nitrates } & Grossman and Krueger (1995) & Inverted-U & $\$ 10,524$ \\
\hline & Cole et al. (1997) & Inverted-U & $\$ 15,600$ \\
\hline Arsenic & Grossman and Krueger (1995) & Inverted-U & $\$ 4,900$ \\
\hline \multirow{2}{*}{ Urban Sanitation } & Shafik and Bandyopadhyay (1992) & Linear with positive slope & N/A \\
\hline & Shafik (1994) & Linear with negative slope & N/A \\
\hline \multirow{2}{*}{ Access to Sanitation } & Torras and Boyce (1998) & Cubic (excluding inequality) & $\$ 10,957$ and $\$ 16,852$ \\
\hline & Torras and Boyce (1998) & Linear with positive slope (including inequality) & N/A \\
\hline
\end{tabular}

Notes: See Table 1.

\footnotetext{
${ }^{4}$ High levels of faecal coliforms result from untreated human wastes that often carry disease.
} 
Table 3: Deforestation

\begin{tabular}{||l|l|c||}
\hline \hline Author(s) & Shape & $\begin{array}{c}\text { Turning Point(s) } \\
{[\$ \text { per capita (1985)] }}\end{array}$ \\
\hline \hline Shafik and Bandyopadhyay (1992) & No Significant Shape & N/A \\
\hline Panayotou (1993) & Inverted-U & $\$ 823$ \\
\hline Cropper and Griffiths (1994) & Inverted-U & $\begin{array}{c}\$ 4,760 \text { (Africa) } \\
\$ 5,420 \text { (Latin America) }\end{array}$ \\
\hline Antle and Heidebrink (1995) & Inverted-U & $\$ 2,049$ \\
\hline Koop and Tole (1999) & No significant shape & N/A \\
\hline
\end{tabular}

Notes: See Table 1. 
Table 4: Other Pollutants

\begin{tabular}{|c|c|c|c|}
\hline Case Study & Author(s) & Shape & $\begin{array}{c}\text { Turning Point(s) } \\
{[\$ \text { per capita }(1985)]}\end{array}$ \\
\hline Automotive Lead Emissions & Hilton and Levinson (1998) & Inverted-U & $\$ 4,000-\$ 11,000$ \\
\hline Household Automotive Lead Emissions & Kahn (1998) & Inverted-U $^{X}$ & $\$ 25,000-\$ 35,000$ \\
\hline \multirow{3}{*}{ Municipal Wastes } & Shafik and Bandyopadhyay (1992) & Linear with positive slope & N/A \\
\hline & Shafik (1994) & Linear with positive slope & N/A \\
\hline & Cole et al. (1997) & Linear with positive slope & N/A \\
\hline Overgrazing & Lekakis (2000) & Linear with positive slope & N/A \\
\hline Number of Environmental Offences & Lekakis (2000) & Linear with positive slope & N/A \\
\hline Traffic Volumes & Cole et al. (1997) & Inverted-U & $\$ 65,300$ \\
\hline Energy & Cole et al. (1997) & Inverted-U & $\$ 22,500$ \\
\hline Toxic Intensity & Hettige et al. (1997) & Inverted-U ${ }^{X}$ & $\$ 12,790$ \\
\hline Heavy Metals & Rock (1996) & Inverted-U & $\$ 10,800$ \\
\hline Agricultural Land Use & James (1999) & Inverted-U & $\$ 1,300$ \\
\hline Cropland Use & James (1999) & Inverted-U & $\$ 1,540$ \\
\hline Pasture Land Use & James (1999) & Inverted-U & $\$ 957$ \\
\hline Volatile Organic Carbon & Carson et al. (1997) & Negative relationship $^{X}$ & N/A \\
\hline \multirow{3}{*}{ Hazardous Waste } & Berrens et al. (1997) & Inverted-U & $\$ 20,253$ \\
\hline & Berrens et al. (1997) & Inverted-U & $\$ 17,679$ \\
\hline & Wang et al. (1998) & Inverted-U & $\$ 23,000$ (\$US 1990) \\
\hline
\end{tabular}

Notes: See Table 1 